\title{
Henri Cuche, Vincent Travers: To dare another glance on the relationship between anesthetist and surgeon in 30 questions
}

\author{
Arnette Wolters Kluwer France, booksebooks, 185 pp, softcover, 2009, 25.00 $€$, \\ http://www.web-anesthesie.fr, ISBN 978-2-7184-1213-9, Language: French
}

\author{
Pierre Kehr
}

Received: 24 November 2011 / Accepted: 26 November 2011/Published online: 11 December 2011

(c) Springer-Verlag 2011

This work of the size of a book of pocket constitutes actually a great revolution in the traditional climate of the operating theaters.

It is indeed traditional to oppose these two medical specialities, each one reproaching the other for being always late, never for not taking account of the respective obligations, etc. And yet which the surgeon without the anesthetist would make and who would become the anesthetist if there were no operational indications, whether they are cold "regulated" or hot and urgent.

The two authors, of which one is anesthetist and the other of course surgeon, make ravel in 30 relevant questions the problems and make fall the prejudices.

Are approached successively, the standard day of the two specialists, the medico-legal implications, the organizational aspect, the way of circumventing the stress, the keys for a better relation, each one of these chapters detailing the various points.

Very didactic are the last pages which show in the form of tables the potential causes of conflict at the time one-day operational imaginary. Each table is divided into three columns, the first making a statement on the situation, the second the potential conflict and the third the solutions to be brought.

Splendid little book that should be in the pocket of all the surgical and anesthetic blouses!
Oser un autre regard sur la relation entre anesthésiste et chirurgien en 30 questions

Cet ouvrage de la taille d'un livre de poche constitue en réalité une grande révolution dans le climat traditionnel des salles d 'opération. Il est en effet classique d'opposer ces deux spécialités, chacune reprochant à l'autre d'être toujours en retard, de ne jamais tenir compte des obligations respectives, etc. Et pourtant que ferait le chirurgien sans l'anesthésiste et que deviendrait l'anesthésiste s'il n'y avait pas d'indications opératoires, qu'elles soient froides, « réglées » ou chaudes et urgentes.

Les deux auteurs, dont l'un est anesthésiste et l'autre bien entendu chirurgien font défiler en trente questions pertinentes la problématique et font tomber les préjugés.

Sont abordés successivement, la journée type des deux spécialistes, les implications médico-légales, l'aspect organisationnel, la façon de contourner le stress, les clés pour une meilleure relation, chacun de ces chapitres détaillant les différents points.

Très didactiques sont les dernières pages qui reprennent sous forme de tableaux les causes potentielles de conflit lors d'une journée opératoire imaginaire. Chaque tableau est divisé en trois colonnes, la première exposant la situation, la deuxième le conflit potentiel et la troisième les solutions à apporter.

Magnifique petit livre qui devrait se trouver dans la poche de toutes les blouses chirurgicales et anesthésiques!

Conflict of interest None.

P. Kehr $(\bowtie)$

Strasbourg, France

e-mail: kehrpier@aol.com 